This is an electronic reprint of the original article. This reprint may differ from the original in pagination and typographic detail.

Author(s): Kotiaho, Janne Sakari

Title: $\quad$ On effective biodiversity conservation, sustainability of bioeconomy, and honesty of the Finnish forest policy

Year: $\quad 2017$

Version:

Please cite the original version:

Kotiaho, J. S. (2017). On effective biodiversity conservation, sustainability of bioeconomy, and honesty of the Finnish forest policy. Annales Zoologici Fennici, 54(1-4), 13-25. https://doi.org/10.5735/086.054.0104

All material supplied via JYX is protected by copyright and other intellectual property rights, and duplication or sale of all or part of any of the repository collections is not permitted, except that material may be duplicated by you for your research use or educational purposes in electronic or print form. You must obtain permission for any other use. Electronic or print copies may not be offered, whether for sale or otherwise to anyone who is not an authorised user. 


\title{
On effective biodiversity conservation, sustainability of bioeconomy, and honesty of the Finnish forest policy
}

\author{
Janne S. Kotiaho
}

\begin{abstract}
Department of Biological and Environmental Science, P.O. Box 35, Fl-40014 University of Jyväskylä, Finland (e-mail: janne.kotiaho@jyu.fi)
\end{abstract}

Received 7 Nov. 2016, final version received 9 Dec. 2016, accepted 12 Dec. 2016

Kotiaho, J. S. 2017: On effective biodiversity conservation, sustainability of bioeconomy, and honesty of the Finnish forest policy. - Ann. Zool. Fennici 54: 13-25.

Dependence of humans on biodiversity is absolute - there is no possibility of our survival without a substantial fraction of today's biodiversity (Hanski 1997, 2005a). What this substantial fraction exactly means is a question to which science has no answer and perhaps will never have. However, if we consider all the things species and ecosystems produce to support our everyday life, the list is long: nearly all food, medicines, as well as materials for clothing, manufacturing and construction, never mind the indispensable ecosystem functions, such as the biogeochemical processes without which waste would accumulate and productivity of ecosystems decline, or the recent 'biodiversity hypothesis' according to which the biodiversity in our living environment might protect us against many chronic diseases related to inflammation such as asthma and allergies, autoimmune diseases, many cancers and even obesity and depression (EASAC 2005, MEA 2005, von Hertzen et al. 2011, Hanski et al. 2012, Hanski 2014a, 2016a, 2016d, Ruokolainen et al. 2015)

Ilkka Hanski was an exceptional natural scientist not only because of his science but also because he was very active in writing for the general public in Finnish. For me personally Ilkka was, and still is, a source of inspiration and this article is founded on two separate but still related pillars inspired by the work of Ilkka. I first examine one of Ilkka's relatively recent suggestions for a practical solution to the problem of how we can increase the conservation area network even in areas heavily dominated by humans such as southern Finland. Second, I explore the concept of sustainability and with an analysis of some National Forestry Inventory data from Finland illustrate that the official stance on sustainability of the Finnish forestry sector is based on intentional delusion of ecological sustainability.

As a tribute to Ilkka's spirit of trying hard to make the society better for people and the nature, and to mainstream scientific rational thinking (Hanski 2002a, Pasanen \& Käkelä 2010), I use several of Ilkka's more popular writings in Finnish. In these writings, Ilkka expressed his acute critique towards the Finnish forest policy and our society in general much more than what can be found from most of his more conventional scientific articles. In addition, these writings, some of which are based on interviews of Ilkka, illustrate that he indeed was not 'only' an ecologist or biologist, but an intelligent clear minded person deeply interested in policy, society and academia (Hanski 1997, 2014b, 2016a, 2016b), human health and future (Hanski 2009b, 2014a, 2016d, Herzen et al. 2011, Hanski et al. 2012, 
Haahtela \& Hanski 2015, Ruokolainen et al. 2015, Furman \& Hanski 2016), scientometrics (Hanski 2006) and for example the quality of popular science literature translations (Hanski 2003a, 2010).

\section{From third-of-third to third-of-half}

In February 2013, Ilkka was invited to provide a metapopulation perspective on protected area selection for a Finnish Ministry of the Environment multi-stakeholder working group, the member of which I was, and the purpose of which was twofold: first, to map and prioritize nationally and regionally the ecologically most valuable peatlands, and second, to suggest for protection about 100000 ha of these such that the selected peatlands would best complement the existing Finnish peatland conservation area network (Alanen \& Aapala 2015).

In this kind of multi-stakeholder working group, like in many discussions that are not exclusively academic, multiple aspects may appear as desired, but turn out to be mutually exclusive when subjected to a more detailed scrutiny. One such pair of desires that came up in this working group was the requirement that regionally rare or unique peatland habitat type patches should be given high priority to be protected and that simultaneously the peatlands that are selected for protection should be either large or well connected to the existing peatland conservation area network, or at least to each other. It appears to be somewhat intrinsic tendency of human psychology to give high value to almost whatever item which is rare [evident in hobby collections, trophy hunting, consumption of rare species as luxury food items and even in ecotourism (Slone et al. 1997, Courchamp et al. 2006)]. Therefore, the consideration of local quality or existence of rare species in the habitat patch easily overrides connectivity or spatial distribution of the habitat patches in general, never mind temporal dynamics of populations which clearly are more difficult for human species to perceive (Hanski 2002a, 2008a, and S. Kareksela unpubl. data). However, if the few remaining good quality habitat patches are small, or at least not very large, and they are embedded in a landscape that has recently i.e., during the past few decades, experienced substantial habitat loss and fragmentation, the patches can be expected to show a transient excess of rare species (Hanski \& Ovaskainen 2000, 2002, Ovaskainen \& Hanski 2002). Thus, it may be that the specialist species inhabiting the rare habitat patches still remaining are factually under extinction debt and have low probability of persisting for long-term (Hanski 2000). Ilkka's presentation made it clear that in practical conservation work it is important to recognize that some of these species are likely to be 'living dead' (Hanski \& Ovaskainen 2002), and it may be a fatal mistake to assume that all extant species would have viable populations even if any additional loss and fragmentation of the habitat were to be prevented by inclusion to a conservation area network.

Ilkka focused on three aspects in his presentation: what happens to isolated small populations and why, importance of the network of local populations, and how should we work towards the Aichi biodiversity target (https://www.cbd. int/sp/targets/) of expanding the protected area network to cover at least $17 \%$ of the land area by 2020. When addressing the first two questions, he directed some piercing critique to the statements and requirements of the Finnish Forest Act, that was at the time under revision. According to the revised Act (20 Dec. 2013/1085), "especially valuable for biodiversity are woodland key habitats that are in a natural or seminatural state, are small sized or otherwise not valuable for forestry sector, and are easily distinguished from the surrounding forest habitat" (translation is mine). Ilkka pinpointed that neither the requirement of small size nor the low value for forestry sector are characteristics that would make habitats valuable for biodiversity but quite the contrary; the requirement of small size makes them less valuable for biodiversity. He further illustrated the point with results from a meta-analysis (Timonen et al. 2011), according to which in Finland the woodland key habitats are on average 0.7 ha (median $=0.35$ ha; Kotiaho \& Selonen 2006) and have no more endangered species than the ordinary managed forest, while the size of woodland key habitats in Sweden are nearly an order of magnitude greater averaging 4.6 ha and harbour significantly more 
endangered species than ordinary managed forests. For those familiar with Ilkka's earlier writings this critique on 'precision conservation', an idea already existing in the Finnish Forest Act before the revision (12 Dec. 1996/1093), was perhaps not unexpected (see e.g. Hanski 2000, 2002a, 2003b, 2005a, 2005b, 2006b, 2008b, 2009a, 2013a, 2013b, Jussila 2010, Pasanen \& Käkelä 2010). In his own words: "What we have here is a twisted argument that is based on a completely fallacious definition of a valuable habitat for biodiversity as small-sized fragments of forest, almost as if they would be valuable just because of their smallness and distinctness. [...] For Finland in particular, one may conclude that the WKHs [woodland key habitats] are far too small, and they are too far apart from each other, to make a significant contribution to conservation of the 100s and even 1,000s of threatened species" (Hanski 2008b).

Ilkka reminded the working group again that even if the target is area-based i.e., to protect $17 \%$ of the area, it matters where the area is and how it is distributed in the landscape. Based on some examples (Andrén 1994, Hanski \& Ovaskainen 2002, Pardini et al. 2010), Ilkka illustrated that landscapes that contain only $10 \%$ of the former habitat cover for the specialist species are frequently reported to have reduced species numbers or population density. However, when the habitat cover of the landscape approaches $30 \%$, such negative effects are increasingly often no longer evident. From these observations, and a brief detour to the already well established genetic viability problems of small populations (Charlesworth \& Willis 2009, Mattila et al. 2012, Pekkala et al. 2014), Ilkka moved on to some of his own simulation work (Hanski et al. 2013, Rybicki \& Hanski 2013). Based on these he concluded that while $10 \%$ of the total habitat area is too little in general, it may be enough even for the specialist species if it is aggregated in large enough networks of well-connected habitat patch clusters that each have approximately $30 \%$, or even a little more, habitat cover left. His simulations were compelling because they show that the proportion of species surviving is much greater in a landscape where the same number of similarly sized habitat patches is clustered, than when they are randomly distributed. His main message to the working group was that protection where habitat fragments to be protected are clustered on what he called multi-use conservation landscapes is more effective because with the same area protected you can ensure the survival of more species.

It is undisputable that Ilkka was a great spokesman for the Finnish nature conservation, but he was also very clear about the challenges in establishing large continuous protected areas in places that would be important for biodiversity. More or less everywhere on the planet most of such important areas have already been converted to human use and are not available for conservation simply because they are generally the most productive landscapes that are simultaneously needed to supply resources and fulfil the increasing needs of the growing human population (see also e.g. Ehrlich 1968, Hardin 1968). Ilkka was tirelessly reminding that even if the protection situation of the Finnish forests may appear good on paper and perhaps even in the light of the overall numbers, the situation is far from good because " $90 \%$ of the protected areas are located north of $66^{\circ} \mathrm{N}$, and a very large fraction of these northern 'forests' are so barren that they have stunted mountain birch at best" (Hanski 2011). He was concerned that the magnitude of the challenge to increase the protected area network also in southern Finland was not understood by the relevant administrators and decision makers (Hanski 2013a). Given that Ilkka himself was clear about the challenge, he occupied his mind with a quest for solving the practical conservation problem: Provided real political will would exist, "how can [we] achieve the target of [...] protecting at least $17 \%$ of land area" (Rybicki \& Hanski 2013).

Perhaps Ilkka's frustration with the poor and diminishing potential of the Finnish Forest Act to maintain forest biodiversity, combined with his life-long work on the influence of the distribution of habitat patches on the persistence of populations in the fragmented landscapes (Hanski et al. 1998, 2013, Hanski 1999, 2016a, 2016d, Hanski \& Gaggiotti 2004), and his insight, that the relative roles of habitat quality, fragment area and connectivity depend on landscape structure and heterogeneity (Hanski 2005) propelled 
the practical conservation solution he called the "third-of-third" rule-of-thumb (Hanski 2011, 2016a, Rybicki \& Hanski 2013, see also Hanski 2003b). As he expressed it, the basic idea is that: " $a$ third of the land area is managed as multi-use conservation landscapes (CL), within which a third of the area is protected. This means that a third of the third, about $10 \%$ of the total area, is protected,..." (Hanski 2011).

As the third-of-third rule-of-thumb is meant to be a practical tool, Ilkka originally also published a numerical example to guide the practical work. He suggested that for the metapopulations to be viable within the multi-use conservation landscapes, each of them should be some tens of thousands of hectares in size and that for example a 20000 ha multi-use conservation landscape should have approximately 6500 ha of protected habitat in some 100 fragments (Hanski 2011). While the actual numbers will vary case by case and area by area, specific to southern Finland Ilkka later suggested figures somewhat smaller to the original ones i.e., 10000 ha multiuse conservation landscapes within which the protected habitat patches would range from 10 to 100 ha (Hanski 2013a). What is important to consider when planning and developing the future expansion of the protected area network, is that the current protected area network in Finland, as well as in most other countries, is not representative of the habitat types or regions (Hanski 2011, 2013a, 2016a).

I find the third-of-third rule-of-thumb an appealing and potent approach for future expansions of the protected area networks. There are nevertheless two issues that should be considered, the first of which I also discussed with Ilkka. By the time Ilkka published the above-mentioned simulation study (Rybicki \& Hanski 2013), I was already familiar with his third-of-third rule-ofthumb idea. However, the original idea (Hanski 2011) was reiterated in the discussion of the simulation paper under the section on practical implications. Reading about it again made me realize that there is another side to the coin of the third-of-third idea, and that was the two thirds. I discussed the other side of the coin with my colleague Panu Halme, and we ended up writing a commentary on the simulation paper (Kotiaho \& Halme 2014). The point of our commentary can be expressed in one sentence borrowed from Gilbert (2011): "because resources are finite, every sensible thing we do is another sensible thing we don't'. When we decide to cluster the habitat patches in the multi-use conservation landscapes that cover one third of the landscape, we simultaneously make a decision to write off the further protection of two thirds of the landscape (Kotiaho \& Halme 2014, see also Bottrill et al. 2008). Before sending our commentary to Ecology Letters, which was the original outlet of Ilkka's simulation paper, we asked Ilkka to provide some comments on our manuscript that we would then send along with our commentary to the journal. Ilkka was very constructive in his comments but it did not help - our commentary was rejected. Later we succeeded to publish the commentary with Proceedings of Peerage of Science, a journal focusing exclusively on publishing peer reviewed commentaries.

If the society is going to utilize Ilkka's insight and results and start working towards the multi-use conservation landscapes as an effective mean for biodiversity conservation, there are several practical aspects that need to be resolved. While Ilkka did not explicitly elaborate on what he meant by the multiple-use of the multi-use conservation landscapes, we were inspired about the idea, and explored in another paper what this might mean (Halme \& Kotiaho 2013). Among few other things, we suggested that the currently evenly distributed miniscule efforts to maintain biodiversity in managed forests should be clustered in the multi-use conservation landscapes and an income redistribution system developed that would take care of the equity of land owners in the different types of landscapes. These miniscule conservation efforts include for example retention trees, proportion of cutting residues and proportion of stumps that certification and best practice guidelines request to be left on every harvested plot in the landscape. While indeed the efforts are miniscule when scattered to whole landscape at the stand level, they would make a difference if aggregated to the multi-use conservation landscapes.

What we did not consider at the time is that some businesses are fast to exploit arising opportunities. Therefore, if indeed the society is starting to work towards the clustering idea in the 
nature conservation, care needs to be taken that the increased or intensified exploitation of the two thirds of the landscape is not allowed before the multi-use conservation landscapes are really established as well.

My final note on the third-of-third is that I find it less than satisfying that it returns only about $10 \%$ total area protected, when the target agreed is $17 \%$. To be clear, when Ilkka first introduced the idea he explicitly explained that " a third of the third, about 10\% of the total area [...] is less than the target set in Nagoya, but this $10 \%$ is in addition to the existing national parks and other protected areas" (Hanski 2011). I am concerned that if the rule-of-thumb is adopted by the global society of conservation professionals as it is, this assumption will easily be overlooked and the overall reality might degenerate to be $10 \%$. Moreover, the fact that the $10 \%$ addition together with the existing protected areas would take us close to $17 \%$, is specific to Finland and as such the rule-of-thumb Ilkka suggested is not universally applicable. To make the rule applicable across nations, I suggest the existing conservation areas should be built to the ruleof-thumb. To do this, I suggest that rather than about third-of-third, we should be talking about a third-of-half rule-of-thumb because that would return approximately 17\% total area protected. Then existing protected areas could function as core areas for the new multi-use landscapes into which we could concentrate all the efforts made for protecting biodiversity.

\section{Acceptability of Finnish forest policy and bioeconomy is based on social delusion of ecological sustainability}

The concept of sustainability emerged in forestry already over two centuries ago, and it was described to mean that one should never harvest more than what the forest yields in new growth (Wiersum 1995, Wilderer 2007). In Finland, the current public discussion about the sustainability of forestry still appears to be nearly exclusively about securing a regular long-term production of wood products, although for decades it has been obvious that forest management should focus not only on timber and pulpwood, but that it should aim at broader provision of human-valued products and services including protection of forest biodiversity (Jalonen et al. 2006, Kuhlman \& Farrington 2010).

It was the report of the UN World Commission on Environment and Development, that defined the concept of sustainability the way it is generally understood today (WCED 1987). In the crux of it, sustainability was described to be about the real contradiction which exists between the long-term sustainability and short-term welfare of humanity (Kuhlman \& Farrington 2010). In the words of the Commission (WCED 1987), sustainable development is "development that meets the needs of the present without compromising the ability of future generations to meet their own needs".

Today sustainability is almost exclusively understood as having three dimensions. These dimensions were first time captured by the UN in its Agenda for Development (UN 1997): "Development is a multidimensional undertaking to achieve a higher quality of life for all people. Economic development, social development and environmental protection are interdependent and mutually reinforcing components of sustainable development".

While it is often assumed that the economic, social and environmental dimensions should have equal weights, this argument has been eloquently refuted by Kuhlman and Harrington (2010): "socio-economic aspects are mostly about the well-being of the present generation and environmental ones are about caring for the future, this means the former become twice as important as the latter". This makes the equal importance to be in direct contradiction with the spirit of the sustainability, according to which development should not take place at the expense of the future generations.

In March 2016 Ilkka criticized the current Finnish Government about their 'vision' about the future of scientific research in Finland (Hanski 2016b). Ilkka explained that the Government thinks that basic research stemming from the curiosity of the researchers is a luxury Finland cannot afford in the current economic crisis. Leading politicians are of the opinion that Finland needs research that increases our 
competitiveness and economic growth (see also Hanski 2009b) and that the goals of education and research need to be adjusted accordingly. Ilkka pointed out that development that is based on continuous fast economic growth should be added to the list of the 'wicked problems' of mankind in particular because one aspect of it is often overlooked: "Fast growth in a dynamic system that has strong feedbacks, such as global economy, increases instability" (Hanski 2016b). In Ilkka's mind it was an important challenge for the future research to be able to determine the requirements needed to decouple economy from the obligation of growth. "Green growth is not the answer, if the stress in on the word growth" (Hanski 2016b).

I find it rather common among natural scientists to dismiss the importance of words. However, in humanities it is clear that it matters how we use the words, and indeed, the choice of words often reveals more than the literal meaning of the text alone (Garrard 2012, Herlin 2012). Thus, I was delighted to see that Ilkka criticized the use of green growth. For the same reason I have been criticizing and making an effort to change the expression 'sustainable use' into 'sustainability of use'. For me the difference is significant because the latter unambiguously stresses the sustainability rather than the use. In particular, when we talk about enhancing something this difference is amplified. As an example you can consider the difference between "increase the sustainable use" vs. "increase the sustainability of use".

Finnish forestry sector with its many lobbyists, including the Ministry of Agriculture and Forestry and the Natural Research Institute Finland (which the former controls through funding), appear to be intentionally abusing the expression 'sustainable use'. If you ask nearly anybody, the truth for the Finnish society is that our forests are growing more than ever. The 'truth' has been fashioned, no doubt, by the endless good news from the forestry sector stressing that Finnish economy is based on forestry and that further economic growth can be expected because we can increase the annual sustainable use of forests by $28 \%$ or in total increase the harvest of wood from $69 \mathrm{Mm}^{3}$ in 2013 to $88 \mathrm{Mm}^{3}$ by 2025 (MMM 2015).
It matters that the forestry lobby is using the word sustainable in such news and documents because for most people the meaning of sustainability is in line with the true spirit of the sustainability: development should not take place at the expense of the future generations. However, it is abundantly clear that the use of Finnish forests is far from being sustainable the way sustainability should really be understood (e.g., Hanski 2002a, 2007, 2008b, 2009b, 2013a, 2013b, 2016a, 2016b, Hanski et al. 2007, Jalonen et al. 2006, Jussila 2010).

To illustrate the point, we can consider the two aspects of boreal forests that are particularly important for the biodiversity: the area of oldgrowth forests and the amount of dead wood (Hanski 2005b, 2016a, Jalonen et al 2006). To assess the age distribution and in particular the development of the old-growth forests in Finland, I accessed the National Forestry Inventory data (Finnish Year Book of Forestry 2012 table 1.12 and http://www.metla.fi/metinfo/vmi/). From there one can extract information on the forest area covered by different age classes of forest from before 1952 until 2011. I did this to analyse whether the age structure of the forests in Finland has been changing. To be in line with true sustainable development, the contemporary use of forests for the desired economic growth should come without compromising the ability of future generations to meet their own needs i.e. to enjoy biodiversity and, indeed, to harvest timber the same way we have been able to do. My hypothesis was that for this to be the case, there should not be very large changes in the overall age structure of the forests in time.

It is immediately obvious from the data (see Fig. 1A) that the area of very young forests has been increasing although the increase was decelerating, and that the area of old-growth forests simultaneously and steadily decreased. During the about 60 years, the area of less than 20-yearold forests increased by $275 \%$ and the area of over 140 -year-old forests decreased by $51 \%$.

While the area of younger age classes increased by on average around $300 \mathrm{~km}^{2}$ yearly (see Fig. 1B), the area of older forests was decreasing and the greatest annual decrease of about $200 \mathrm{~km}^{2}$ was in the oldest forest-stand age class of over 140 years of age. As a sour icing on 

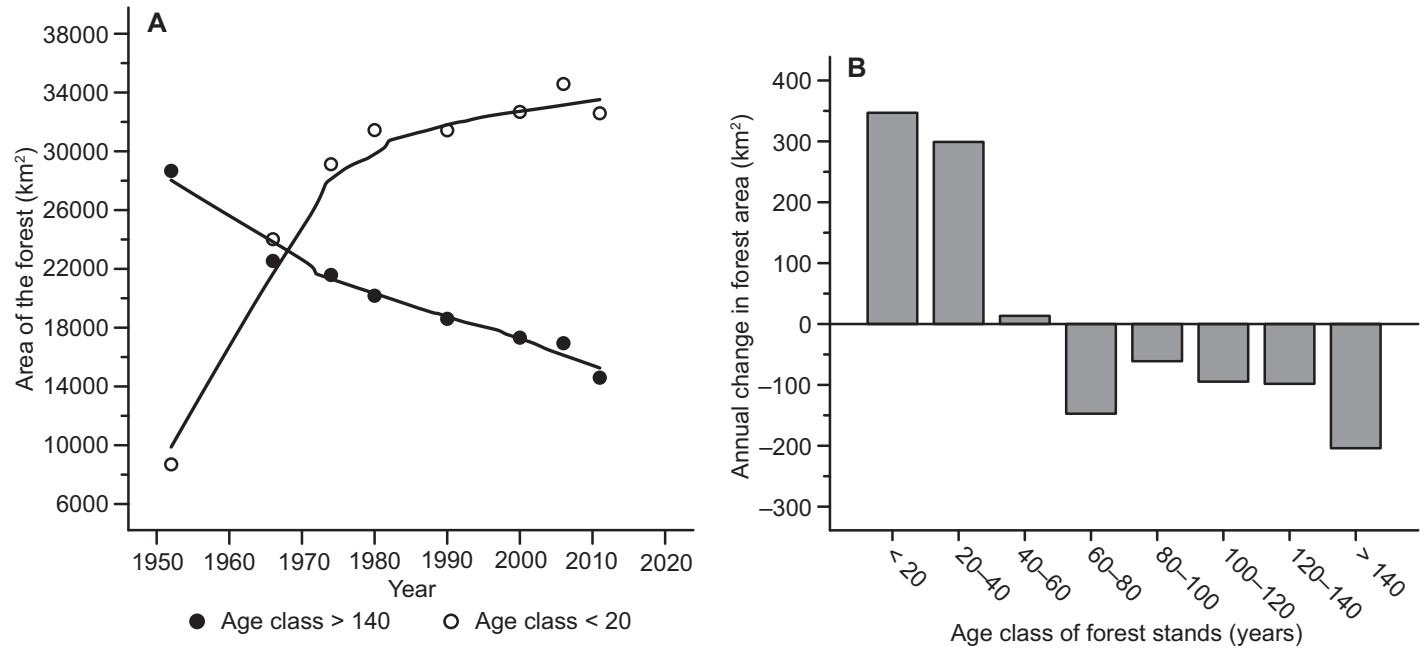

Fig. 1. (A) Area of the forest $\left(\mathrm{km}^{2}\right)$ in forest-stand age classes $<20$ years and $>140$ years as a function of the inventory year from 1952 to 2011. (B) Annual change in forest area $\left(\mathrm{km}^{2}\right)$ in different forest stand age classes from 1952 to 2011. In B the annual change is derived from a linear regression of area on year separately for each age class. Data for both panels are from the Finnish Year Book of Forestry (2012: table 1.12); the complete VMI 2011 data are from http://www.metla.fi/metinfo/vmi/. Each inventory was carried out during several years and for the figure and for the calculation of the regression coefficients the median year is assigned to each inventory. Total area assigned to be forest land in Finland varied across the inventories between 17352 and 20338 km². This variation is taken into account by normalising the area across the inventories in relation to the greatest area. This was done by multiplying the area of each of the age classes in a given inventory by $\left(20338 \mathrm{~km}^{2} /\right.$ total area $\left(\mathrm{km}^{2}\right)$ of the inventory). The area variation across inventories is modest and thus normalising has only small effect on the areas and does not alter any of the conclusions.

the cake, we can have a look at the behaviour of forests stands over 160 years old that have been tabulated separately in the last three inventories NFI9-NFI11. The areas of such forest stands were 13020,12398 and $9971 \mathrm{~km}^{2}$, in NFI9, NFI10 and NFI11, respectively. Thus, during the last ca. 15 years, a staggering $23.4 \%$ of the natural and near-natural old-growth forests was lost. Ten years ago on 7 February 2007, Ilkka handed over the so called 'researcher letter' signed by him and 77 of his colleagues (including me) to the Minister of Agriculture and Forestry Juha Korkeaoja requesting to stop the harvest of the natural and near-natural old-growth forests in Finland. In the letter it was stated that during the last decade about $1000 \mathrm{~km}^{2}$ of natural and near-natural old-growth forests in Finland had been lost, which illustrates that the rate of oldgrowth forest loss has actually increased since the date of letter if compared with the numbers cited above (about $3000 \mathrm{~km}^{2}$ in 15 years). In the light of those numbers, it seems rather clear that the request of the academic forest biodiversity experts has been completely ignored. The numbers also illustrate that Ilkka's optimism or hope about a decade ago (Hanski \& Ruuhijärvi 2006), that "timber harvesting in the natural or near natural forests of Northern Finland will become intolerable due to pressures from international forest product customers" has unfortunately not been realized. Thus, any claims about the sustainability of the current, never mind the planned increasing rates of harvest (MMM 2015) must be rejected as disinformation, deliberate dishonesties and propaganda.

In Finland, a lot of public discussion has been around the amount of dead wood in managed forests. With all the new sustainable forest management initiatives and other significant changes in the forestry practises, it is commonly stated and believed that the amount of dead wood is increasing. When there is no observable effect, the argument you may have heard is that "we just have to have the patience to wait for the positive impact of these new measures" (Hanski 2002b). Comparison of the available data between NFI9 
and NFI11 proves otherwise: during the ca. 15 years the total volume of dead wood did not increase but rather it decreased by a total of 0.7 $\mathrm{Mm}^{3}$ from $126.8 \mathrm{Mm}^{3}\left(5.8 \mathrm{~m}^{3} \mathrm{ha}^{-1}\right)$ to $126.1 \mathrm{Mm}^{3}$ $\left(5.7 \mathrm{~m}^{3} \mathrm{ha}^{-1}\right)$ (https://www.luke.fi/wp-content/ uploads/2015/03/Taulukkoliite.pdf). The average decline at the scale relevant for populations is very small, and if the forests would have the amount of dead wood they naturally have without forest management, such decline would actually be irrelevant. However, the current amount of dead wood in the forests is far from the natural amounts. The amount of dead wood is naturally dynamic and varies depending on the specifics of the region and forest type, but in natural conditions it is estimated to be anywhere from less than 60 to over $120 \mathrm{~m}^{3} \mathrm{ha}^{-1}$ (Siitonen 2001, Kotiaho et al. 2015). If the average was around $100 \mathrm{~m}^{3}$ $\mathrm{ha}^{-1}$ in a natural forest, and now there is about $5 \mathrm{~m}^{3} \mathrm{ha}^{-1}$, forest management removed $95 \%$ of the resources from the 4000-5000 species that are dependent on dead wood (Siitonen 2001). Just imagine if the global human population, that will reach 7500 million by the time this article is published, would be denied $95 \%$ of the resources we currently have. The catastrophe would be colossal.

These two examples of the state of Finnish forests make the message crystal clear: instead of promoting usage of the forests in sustainable manner, the Finnish forest policy is driving the forests to be void of old growth and dead wood. Thus, while already more than 100 species of animals, plants and fungi have gone extinct from the Finnish forests, it seems likely that with the current forest policy we can kiss goodbye another ca. 1000 species that were estimated to be under extinction debt already over a decade ago (Hanski 2000, 2003b, Siitonen \& Hanski 2004). I think it is time to be serious about the sustainability. Instead of promoting the use and growth under the greenwash of sustainability, we must start talking about increasing the sustainability of the use and focusing on establishing conditions for the inevitable necessity of degrowth (see e.g. Kallis 2011, Hanski 2016b). In fact, the situation in Finland seems to be such that the forestry sector as a whole is breaking the forest law of Finland, the purpose of which is to "promote the economically, ecologically and socially sustainable management and use of forests such that forests yield sustained economical revenue while simultaneously the biological diversity is maintained" (12 Dec. 1996/1093, §1, translation is mine). How is it possible that we as a society, and in particular our decision makers, are turning a blind eye to the fact that biological diversity is already declining and thus not maintained as requested by our law, and that the survival of many more species is under serious threat with the current forest policy, never mind the planned significant increases of harvest?

It may be worth noting that some governmental research institutes may try to challenge the above factual loss of species and old-growth forests by arguing that based on the data available it is difficult or impossible to clearly determine whether species are permanently extinct in Finland, and what exactly is the old-growth or natural forest. Based on these 'challenges', their argument is that the cut forests that were over 140 or 160 years old were just normal, managed forests and as such not important for biodiversity. This is outright ridiculous. Just consider which one is better for biodiversity in 2050, the young single-species even-aged forest planted after the clear cut, or the nearly 200-year-old forest that would be extant had it not been cut. They may still try to do this, as this is exactly what they tried to do before [(Annila et al. 2002, Hanski 2002b, 2002c, Raitio \& Puttonen 2007, Hanski et al. 2007; see also the dissenting opinion by the forestry sector and my reply to it in a report in which we derived the framework for assessing and reversing ecosystem degradation (Kaatra et al. 2015 vs. Kotiaho 2015)].

I wrote this paper in October 2016 and when I had already finished the above sections, I came across a hot off the press report on the effects of three different bioeconomy scenarios on the structural elements of forests important for biological diversity (Korhonen et al. 2016). I read it immediately. The central conclusion stated in the report is that all measures helping biodiversity should be intensified in order to ensure the ecological sustainability of the bioeconomy. At first sight this is a fair recommendation. However, instead of should, I would have said the measures shall be intensified. Even if the measures would be intensified, there is another problem: 
rather than really helping the biodiversity, the chosen measures will only partially mitigate the devastating effects of the increasing harvests on biodiversity, and our forestry sector will remain far from the goal of no-net-loss of biodiversity and ecosystem condition. I could not refrain myself from pointing out also a few other issues about the report as a conclusion to this paper.

First, all of the scenarios are based on increasing harvest and the scenario Korhonen et al. (2016) call the 'basic scenario' means that the harvest will be increased from the current annual ca. $65 \mathrm{Mm}^{3}$ to $73 \mathrm{Mm}^{3}$ which means a $12 \%$ growth in annual harvest. The other two scenarios are based on increasing the harvest to $80 \mathrm{Mm}^{3}$ i.e. an increase by $23 \%$, and, what they call the maximum sustainable harvest from the perspective of wood production, to $88 \mathrm{Mm}^{3}$ i.e. an increase by $35 \%$. It is truly unfortunate that the report only reinforces the 'truth' that forests need to be cut more, and offers no alternatives to the decision makers but to increase the already unsustainable levels of harvest. It would have been fair and indeed very interesting to see what would have happened to the structural elements important for biodiversity had one of the scenarios been business-as-usual i.e., maintaining the current level of harvest. Moreover, I would have expected to see a scenario where the harvest would have been decreased and especially the harvest of the natural and near-natural over 140-year-old forests would have been stopped completely as requested by Ilkka and researcher colleagues a decade ago (Hanski et al. 2007). But no, the starting point of the report seem to be the uncritical assumption that growing harvest is an unavoidable future and the costs or benefits of alternatives are unworthy of exploration. To me the fact that the assignment of the report was to develop the scenarios based on the 'visions' of the Ministry of Agriculture and Forestry (Lehtonen et al. 2016) is not a valid excuse.

Second, it seems that the introductory section on state and past development of forests of Finland is portraying a picture of trees that are getting larger, forests that are getting older and, of course, stressing the overall increase of the annual volume of wood in the forests. What a wonderful situation we have in the forests of Finland! I wonder why the report has chosen for- ests that are over 120 years of age as old-growth forests when such forests are not really that old. Might it have something to do with the need to mask the loss of the truly old-growth forests in Finland? Why is there no concern expressed about the fact that in the past 15 years we lost nearly one fourth of our truly old-growth, over 160 years of age, forests or that the age structure of the forests was pushed hard towards bush of scrubland of less than 20 or 40 years of age (for data see previous section; see also Vilén et al. 2012)? To really understand the state of our forests at the moment, we need to establish a proper point of comparison or the baseline. How far off from the ecological sustainability we are at the moment would be revealed by comparing the current state of forests, not to the heavily degraded state at the beginning of the last century against which nearly everything appears improvement, but to the natural state of the forests (Kotiaho et al. 2015, 2016a, 2016b).

Third, I found interesting the choice of the volume of old, large trees as an important element for biodiversity. While indeed old, large individual trees are likely important, the old, large trees in the report are not trees in old-growth forests or indeed in a forest at all. These are single, large trees scattered evenly and very sparsely across the clear cut landscape. In the simulations, these trees were retained because of the tree retention policy, and in each of the clear cuts $5 \mathrm{~m}^{3} \mathrm{ha}^{-1}$ of retention trees were simulated. The first finding stated already in the abstract of the report is that the volume of old, large trees is increasing and in the results section it is detailed that in the end of the simulations $17 \%-43 \%$ of the volume of old, large trees was due to the retention trees. From fig. 12 in Korhonen et al. (2016) it is evident that the increase in the volume of old, large trees approaches two- to three-fold increase. I was thinking that this might be significant, and started again to think that biodiversity would probably be much better off if these retention trees were indeed aggregated into the multi-use landscapes (Hanski 2011, Rybicki \& Hanski 2013) as suggested earlier by me and my colleague Panu Halme (Halme \& Kotiaho 2013).

Unfortunately, the question about the importance of these trees became unexpectedly irrelevant in the end of the report. It was not explained 
in the methods or in the section on caveats of the calculations, but it was hidden in the very last section on the measures to advance the biodiversity: in reality only half of the amount of retention trees entered into the simulations are left on the clear cuts, and from a third of the clear-cuts some of this half is removed later. These two numbers mean that in reality from $5 \mathrm{~m}^{3}$ used in the simulations, less than half are left and from this yet another $15 \%-100 \%$ is stated in the report to be blown over after the clear cut. When these facts were known to Korhonen et al. (2016) at the time they made the simulations, why did they not adjust the amount of these trees to even approximate the reality? Perhaps the reason was the same as why the current state of affairs in the forests of Finland was portrayed in the introduction to be so wonderful. I find the presentation of results known by Korhonen et al. (2016) to be biased towards overt optimism to be questionable to say the least.

Finally, as pointed out already earlier, the choice of words matters. When discussing the trends of old-growth forests of northern Finland, Korhonen et al. (2016) implied that following a strong decline, the development changed but "still during the last decades the share of the old growth forests has been slightly decreasing" (Korhonen et al. 2016: p. 8). 'Slightly decreasing' is an interesting choice of words, when at the same time the factual numbers describing the development of the area of the over 160-year-old forests show a decline by a quarter during the last 15 years. Moreover, fig. 3 for northern Finland in Korhonen et al. (2016) shows no signs of the implied deceleration of the decline of the over 120-year-old forests. What is going on? Is the claim of Korhonen et al. (2016) an interpretation error or could it be an intentionally crafted delusion about the state of affairs in the Finnish forests?

What about the story about the amount of dead wood? After it is stated, more or less like I explained above, that in the natural forests the amounts of dead wood can be even hundreds of $\mathrm{m}^{3} \mathrm{ha}^{-1}$, the impression of the wonderful current state of Finnish forests continues. Here, the trick was done again by not comparing the current amounts of dead wood to the amounts in the natural state like they should (Kotiaho 2015, Kotiaho et al. 2015, 2016a, 2016b), but the comparison is turned around and the baseline chosen is an even more degraded state: "amount of dead wood has multiplied since the early 1900's" (Korhonen et al. 2016: p. 9). When one compares the current amount of about $5 \mathrm{~m}^{3} \mathrm{ha}^{-1}$ of dead wood, or in fact any number, to a number approaching zero the current state will indeed be many times better. The correct baseline is the natural state.

Had Korhonen et al. (2016) used the natural state baseline, they would have revealed that the increase in dead wood by $1 \mathrm{~m}^{3}$ from 3.5 to $4.5 \mathrm{~m}^{3}$ per ha in two of the scenarios for the southern Finland is around $1 \%$. Based on the increase, it is concluded that this is a positive change for biodiversity, although it is still too little for the more demanding and endangered species. It is intellectually dishonest to state that this $1 \%$ increase is a positive change for biodiversity. From the perspective of over 4000 dead-wood-dependent species, from which we have taken $95 \%$ of their resources, a return of only $1 \%$ over the next few decades is catastrophic news.

In conclusion, my concern is that here we have a report that will be read and used by many to state that yes we can increase the harvest without loss of sustainability of the forestry sector. With the choice of positive words combined with perhaps slight exaggeration in the right contexts and by using inappropriate baselines, the report manages to portray a wonderful current state and even better future for the forests of Finland even if we increase their use by over $10 \%, 20 \%$ or $30 \%$. The bottom line is that even with the current rate of harvest, never mind with the planned increases, the Finnish forest industry is not sustainable (Hanski 2016c). This is evidenced by the radical changes in the forest age structures, rapidly ongoing loss of old-growth forests and the greatly reduced amount of dead wood as compared with the natural state. This statement is further supported by the fact that many forest species have already gone extinct and $36 \%$ of all species under risk of extinction in Finland have forests as their primary habitat type. The rate of decline of species living in forests has slightly decelerated, but the fact is that populations of forest species are nevertheless still in decline (Rassi et al. 2010). Anyone claiming current forestry to be sustainable has either vested interests or does not understand that sustainability means 
development that does not take place at the expense of the future generations.

It may be that the Finnish society decides (as it has) that it is necessary to increase the use of forests. Were this decision made after careful consideration and being fully informed of the negative consequences of such increases to the biodiversity and wellbeing of the future generations, my personal disagreement would be irrelevant. It would be distressing and I would try to influence the decision, but in the end I would have to accept it. However, the society and the decision makers are not well informed: As an example, in February 2016 I was invited to give a presentation about the assessment and reversal of ecosystem degradation for the Environment Committee of the Parliament of Finland. In one section of my talk I explained, like above, that forest management has removed $95 \%$ of the resources from 4000-5000 species that are dependent on dead wood, and I also included the analogy to the colossal humane catastrophe such reduction of resources would cause. The first comment after my talk from one of the Members of the Parliament was "I contest the claim that forest management has caused any harm to forest biodiversity". I am not often speechless but this time it was close.

It is intolerable that the forestry lobby spreads disinformation and is intentionally dishonest about the sustainability of the Finnish forest management. They have managed to create a nationwide delusion about the good state and sustainability of forests and forestry, respectively. It is time for the Finnish society to rid itself of the delusion. Rather than accepting the increased use of forests under the greenwash of sustainability, we must insist forestry sector increases the sustainability of the use.

\section{Acknowledgements}

I thank Ari-Pekka Auvinen, Paul Ehrlich, Jussi Eronen, Atte Komonen, Saija Kuusela and Joona Lehtomäki for very helpful comments on an earlier draft of this paper.

\section{References}

Alanen, A. \& Aapala, K. (eds.) 2015: Soidensuojelutyöryh- män ehdotus soidensuojelun täydentämiseksi. - Ympäristöministeriön raportteja 26/2015.

Annila, E., Järveläinen, V.-P., Keltikangas, M. \& Vehkamäki, S. 2002: Avoimia kysymyksiä Ilkka Hanskille. - Tieteessä tapahtuu 3/2002: 38-40.

Andrén, H. 1994: Effects of habitat fragmentation on birds and mammals in landscapes with different proportions of suitable habitat: a review. - Oikos 71: 355-366.

Bottrill, M. C., Joseph, L. N., Carwardine, J., Bode, M., Cook, C., Game, E. T., Grantham, H., Kark, S., Linke, S., McDonald-Madden, E., Pressey, R. L., Walker, S., Wilson, K. A. \& Possingham, H. P. 2008: Is conservation triage just smart decisionmaking? - Trends Ecol. Evol. 23: 649-654.

Charlesworth, D. \& Willis, J. H. 2009: The genetics of inbreeding depression. - Nat. Rev. Genet. 10: 783-796.

Courchamp, F., Angulo, E., Rivalan, P., Hall, R. J., Signoret, L., Bull, L. \& Meinard, Y. 2006: Rarity value and species extinction: the anthropogenic Allee effect. - PLoS Biol. 4(12): e415, doi:10.1371/journal.pbio.0040415.

Ehrlich, P. R. 1968: The population bomb. - Buccaneer Books, New York.

EASAC 2005: A user's guide to biodiversity indicators. European Academies Science Advisory Council.

Furman, E. \& Hanski, I. 2016: Monimuotoinen luonto on kaikkien etu. - Available at http://www.uutistamo.fi/ monimuotoinen-luonto-kaikkien-etu/.

Garrard, G. 2012: Ecocriticism, 2nd ed. - Routledge, London and New York.

Gilbert, D. 2011: Buried by bad decisions. - Nature 474: 275-277.

Haahtela, T. \& Hanski, I. 2015: Kaupungistuminen haastaa kansanterveystyön. - Lääkärilehti 70: 1129.

Halme, P. \& Kotiaho, J. S. 2013: Keskittämällä kohti ekologisesti ja taloudellisesti kestävää metsätaloutta. - Luonnon Tutkija 117: 31-38.

Hanski, I. 1997: Biodiversiteetin katoaminen. - Duodecim 113: 2411-2416.

Hanski, I. 1999: Metapopulation ecology. — Oxford University Press, New York.

Hanski, I. 2000: Extinction debt and species credit in boreal forests: modelling the consequences of different approaches to biodiversity conservation. - Ann. Zool. Fennici 37: 271-280.

Hanski, I. 2002a: In the midst of ecology, conservation and competing interests. - Ann. Zool. Fennici 39: 183-186.

Hanski, I. 2002b: Vastauksia metsäprofessoreille. - Tieteessä tapahtuu 4/2002: 37-41.

Hanski, I. 2002c: Hanski ei kaihda tieteellistä keskustelua! - Tieteessä tapahtuu 5/2002: 35-36.

Hanski, I. 2003a: Elämän tulevaisuus on turvattu - mutta minkälaisen elämän? - Tieteessä tapahtuu 5/2003: 63-66.

Hanski, I. 2003b: Ekologinen arvio Suomen metsien suojelutarpeesta. - In: Harkki, S., Savola, K. \& Walsh, M. (eds.), Palaako elävä metsä? Metsien suojelun tavoitteita 2000-luvun Suomessa: 18-33. Birlife Finland, Helsinki.

Hanski, I. 2005a: Landscape fragmentation, biodiversity loss and the societal response. - EMBO Reports 6: 388-392.

Hanski, I. 2005b: The shrinking world: ecological conse- 
quences of habitat loss. - Excellence in Ecology Series vol. 14, International Ecological Institute, Oldendorf.

Hanski, I. 2006a: Julkaisuaktiivisuuden megatrendi luonnontieteissä. - Tieteessä tapahtuu 2/2006: 37-39.

Hanski, I. 2006b: Täsmäsuojelun mahdollisuus - vai mahdottomuus. - In: Jalonen, R., Hanski, I., Kuuluvainen, T., Nikinmaa, E., Pelkonen, P., Puttonen, P., Raitio, K. \& Tahvonen, O. (eds.), Uusi metsäkirja: 200-205. Gaudeamus, Helsinki.

Hanski, I. 2007: Miten luonnon monimuotoisuutta syntyy - ja miten sitä häviää? - Duodecim 123: 1540-1542.

Hanski, I. et al. 2007: Avoin kirje maa- ja metsätalousministerille 7.2.2007 Tutkijat vetoavat luonnontilaisten metsien säilyttämisen puolesta. - Available from Registry office of the Ministry of Agriculture and Forestry, Helsinki.

Hanski, I. 2008a: The world that became ruined. - EMBO Reports 9: S34-S36, doi:10.1038/embor.2008.77.

Hanski, I. 2008b: Insect conservation in boreal forests. $-J$. Insect Conserv. 12: 451-454.

Hanski, I. 2009a: Sukupuuton partaalla. - Natura 3/2009: $38-43$.

Hanski, I. 2009b: Luonnon monimuotoisuuden tulevaisuus. - In: Hanski, I, Niiniluoto, I. \& Hetemäki, I. (eds.), Kaikki evoluutiosta: 196-208. Gaudeamus, Helsinki.

Hanski, I. 2010: Evoluution todisteet. - Tieteessä tapahtuи 6/2010: 53-55.

Hanski, I. 2011: Habitat loss, the dynamics of biodiversity, and a perspective on conservation. - Ambio 40: 248-255.

Hanski, I. 2013a: Voidaanko metsien biologisen monimuotoisuuden väheneminen pysäyttää vuoteen 2020 mennessä? Huomioita metsälakiesityksestä. - Metsätieteen aikakausikirja 1: 74-77.

Hanski, I. 2013b: Puun ja kuoren välissä. - Luonnon Tutkija 117: 3 .

Hanski, I. 2014a: Biodiversity, microbes and human wellbeing. - Ethics Sci. Environ. Polit. 14: 19-25.

Hanski, I. 2014b: Suomen tiedeakatemia. - Tieteessä tapahтии 2/1014: 44-45.

Hanski, I. 2016a: Messages from islands: a global biodiversity tour. - University of Chicago Press.

Hanski, I. 2016b: Suomi uhkaa jäädä tiedemaailman takariviin. - Suomen Kuvalehti 3 Mar. 2016. [Available at http://suomenkuvalehti.fi/jutut/kotimaa/suomi-jaa-tiedemaailman-takariviin-akatemiaprofessori-ilkka-hanskin-tiukka-viesti-hallitukselle/?shared=312505-e6d2fba6-999].

Hanski, I. 2016c: Hakkuut syventävät metsäluonnon ahdinkoa. - Mielipide kirjoitus, Helsingin Sanomat 15.3.2016. [Available at http://www.hs.fi/mielipide/art2000002891216.html].

Hanski, I. 2016d: Academician Ilkka Hanski's farewell lecture: a brief biodiversity tour. - Availlable at https://

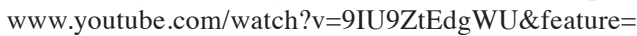
youtu.be

Hanski, I. \& Gaggiotti, O. E. (eds.) 2004: Ecology, genetics, and evolution of metapopulations. - Elsevier Academic Press, Amsterdam.

Hanski, I. \& Ovaskainen, O. 2000: The metapopulation capacity of a fragmented landscape. - Nature 404:
$755-758$.

Hanski, I. \& Ovaskainen, O. 2002: Extinction debt at extinction threshold. - Conservation Biology 16: 666-673.

Hanski, I. \& Ruuhijärvi, R. 2006: Metsien suojelussa 2000-luvulle. - In: Jalonen, R., Hanski, I., Kuuluvainen, T., Nikinmaa, E., Pelkonen, P., Puttonen, P., Raitio, K. \& Tahvonen, O. (eds.) 2006: Uusi metsäkirja: 218-221. Gaudeamus, Helsinki.

Hanski, I., Zurita, G. A., Bellocq, M. I. \& Rybicki, J. 2013: Species-fragmented area relationship. - Proc. Natl. Acad. Sci. USA 110: 12715-12720.

Hanski, I., Lindström, J., Niemelä, J., Pietiäinen, H. \& Ranta, E. 1998: Ekologia. - WSOY, Helsinki.

Hanski, I., Hottola, J., Kuuluvainen, T., Mäkipää, R., Ovaskainen, O.\& Tahvonen, O. 2007: Keskustelussa metsien kestävästä käytöstä ja suojelusta on sivuutettu olennaisia kysymyksiä. - Tieteessä tapahtuи 5/2007: 41-44.

Hanski, I., von Hertzen, L., Fyhrquist, N., Koskinen, K., Torppa, K., Laatikainen, T., Karisola, P., Auvinen, P., Paulin, L., Mäkelä, M. J., Vartiainen E., Kosunen, T. U, Alenius, H. \& Haahtela, T. 2012: Environmental biodiversity, human microbiota, and allergy are interrelated. - Proc. Natl. Acad.Sci. USA 109: 8334-8339.

Hardin, G. 1968: The tragedy of the commons. - Science 162: 1243-1248.

Herlin, I. 2012: Katse kieleen ja ympäristöön. Kielikuvia. Nykysuomen seuran lehti 212: 3-17.

Jalonen, R., Hanski, I., Kuuluvainen, T., Nikinmaa, E., Pelkonen, P., Puttonen, P., Raitio, K. \& Tahvonen, O. (eds.) 2006: Uusi metsäkirja. - Gaudeamus, Helsinki.

Jussila, N. 2010: Vähiin käy. - Vihreälanka 4/2010. [Available at http://www.vihrealanka.fi/lanka-2010/04/ v\%C3\%A4hiin-k\%C3\%A4y].

Kaatra, K., Matveinen, K., Kaipainen, J., Kammonen, A., Seppälä, M., Korhonen, K. T. \& Keskitalo, M. 2015: Eriävä mielipide. - The Finnish Environment 8: 233-237.

Kallis, G. 2011: In defence of degrowth. - Ecological Economics 70: 873-880.

Korhonen, K. T., Auvinen, A.-P., Kuusela, S., Punttila, P., Salminen, O., Siitonen, J., Ahlroth, P., Jäppinen, J.-P. \& Kolström, T. 2016: Biotalouskenaarioiden mukaisten hakkuiden vaikutukset metsien monimuotoisuudelle tärkeisiin rakennepiirteisiin. - Luonnonvara- ja biotalouden tutkimus 51/2016.

Kotiaho, J. S. 2015: Täydentävä lausunto ELITE -työryhmän mietintöön. - The Finnish Environment 8: 241-243.

Kotiaho, J. S., ten Brink, B. \& Harris, J. 2016a: A global baseline for ecosystem recovery. - Nature 532: 37.

Kotiaho, J. S. \& Selonen, V. A. O. 2006: Metsälain erityisen tärkeiden elinympäristöjen kartoituksen laadun ja luotettavuuden analyysi. - Suomen ympäristö 29: 1-65.

Kotiaho, J. S. \& Halme, P. 2014: Aggregating protected habitats embraces implicit habitat conservation triage. — ProcPoS 1:e5, doi:10.14726/procpos.2014.e5.

Kotiaho, J. S., Kuusela, S., Nieminen, N. \& Päivinen, J. (eds.) 2015: Elinympäristöjen tilan edistäminen Suomessa. - The Finnish Environment 8, Ympäristöministeriö, Helsinki.

Kotiaho, J. S., Kuusela, S., Nieminen, E., Päivinen, J. \& Moilanen, A. 2016b: Framework for assessing and reversing 
ecosystem degradation. - Reports of the Ministry of the Environment 15en, Helsinki.

Kuhlman, T. \& Farrington, J. 2010: What is sustainability? - Sustainability 2: 3436-3448.

Lehtonen, A., Salminen, O., Kallio, M., Tuomainen, T. \& Sievänen, R. 2016: Skenaariolaskelmiin perustuva puuston ja metsien kasvihuonekaasutaseen kehitys vuoteen 2045. Selvitys maa- ja metsätalousministeriölle vuoden 2016 energia- ja ilmastostrategian valmistelua varten. - Luonnonvara- ja biotalouden tutkimus 36, Luonnonvarakeskus, Helsinki.

Mattila, A. L., Duplouy, A., Kirjokangas, M., Lehtonen, R., Rastas, P. \& Hanski, I. 2012: High genetic load in an old isolated butterfly population. - Proc. Natl. Acad. Sci. USA 109: 14744-14745.

MEA 2005: Millennium ecosystem assessment. Ecosystems and human well-being: synthesis. - Island Press, Washington DC.

MMM 2015: Kansallinen metsästrategia 2025. Valtioneuvoston periaatepäätös 12.2.2015. - Maa- ja metsätalousministeriö 6/2015.

Ovaskainen, O. \& Hanski, I. 2002: Transient dynamics in metapopulation response to perturbations. - Theoretical Population Biology 61: 285-295.

Pardini, R., Bueno, A. D., Gardner, T. A., Prado, P. I. \& Metzger, J. P. 2010: Beyond the fragmentation threshold hypothesis: regime shifts in biodiversity across fragmented landscapes. - Plos One 5: e13666, doi:10.1371/ journal.pone.0013666.

Pasanen, M. \& Käkelä, J. (eds.) 2010: Ilkka Hanski tietää minne lajit katoavat. - Luonnonsuojelija 1/2010: 14-15

Pekkala, N., Knott, K. E., Kotiaho, J. S., Nissinen, K. \& Puurtinen, M. 2014: The effect of inbreeding rate on fitness, inbreeding depression, and heterosis over a range of inbreeding coefficients. - Evolutionary Applications 7: 1107-1119.

Raitio, H. \& Puttonen, P. 2007: Metsäntutkimuslaitoksen lausunto tutkijoiden kirjeestä maa- ja metsätalousministeriölle 7.2.2007. - Maa- ja metsätalousministeriö, Helsinki.

Rassi, P., Hyvärinen, E., Juslén, A. \& Mannerkoski, I. (eds.) 2010: Suomen lajien uhanalaisuus - punainen kirja 2010. - Ympäristöministeriö \& Suomen ympäristökeskus, Helsinki.

Ruokolainen, L., von Hertzen, L., Fyhrquist, N., Laatikainen, T., Lehtomäki, J., Auvinen, P., Karvonen, A. M., Hyvärinen, A., Tillmann, V., Niemelä, O., Knip, M., Haahtela, T., Pekkanen, J., Hanski, I. 2015: Green areas around homes reduce atopic sensitization in children. - Allergy 70: 195-202.

Rybicki, J. \& Hanski, I. 2013: Species-area relationships and extinctions caused by habitat loss and fragmentation. Ecol. Lett. 16(Suppl. 1): 27-38.

Saccheri, I. J., Kuussaari, M., Kankare, M., Vikman, P., Fortelius, W. \& Hanski, I. 1998: Inbreeding and extinction in a butterfly metapopulation. - Nature 392: 491-494.

Siitonen, J. 2001: Forest management, coarse woody debris and saproxylic organisms: Fennoscandian boreal forests as an example. - Ecological Bulletins 49: 11-41.

Siitonen, J. \& Hanski, I. 2004: Metsälajiston ekologia ja monimuotoisuus. - In: Kuuluvainen, T., Saaristo, L., Keto-Tokoi, P., Kostamo, J., Kuuluvainen, J., Kuusinen, M., Ollikainen, M. \& Salpakivi-Salomaa, P. (eds.), Metsän kätköissä - Suomen metsäluonnon monimuotoisuus: 76-105. Edita, Helsinki.

Slone, T. H., Orsak, L. J. \& Malver, O. 1997: A comparison of price, rarity and cost of butterfly specimens: implications for the insect trade and for habitat conservation. Ecol. Econ. 21: 77-85.

Timonen, J., Gustafsson, L., Kotiaho, J. S. \& Mönkkönen, M. 2011: Hotspots in cold climate: conservation value of woodland key habitats in boreal forests. - Biological Conservation 144: 2061-2067.

UN 1997: Agenda for development. - United Nations, New York, NY.

Valtioneuvosto 2012: Valtioneuvoston periaatepäätös Suomen luonnon monimuotoisuuden suojelun ja kestävän käytön strategiasta vuosiksi 2012-2020, luonnon puolesta - ihmisen hyväksi. - Valtioneuvosto, Helsinki.

WCED 1987: World Commission on Environment and Development (WCED). Our common future. - Oxford University Press, New York, NY.

Wiersum, K. F. 1995: 200 years of sustainability in forestry: lessons from history. - Environ. Manage. 19: 321-329.

Wilderer, P. A. 2007: Sustainable water resource management: The science behind the scene. - Sustain. Sci. 2: $1-4$.

Vilén, T., Gunia, K., Verkerk, P. J., Seidl, R., Schelhaas, M.-J., Lindner, M. \& Bellassen, V. 2012: Reconstructed forest age structure in Europe 1950-2010. - Forest Ecology and Management 286: 203-218.

von Hertzen, L., Hanski, I. \& Haahtela, T. 2011: Natural immunity. - EMBO Reports 12: 1089-1093, doi:10.1038/embor.2011.195. 